\title{
Epidemiology of paediatric poisoning presenting to a children's emergency department in Singapore over a five-year period
}

\author{
Shao Hui $\underline{K o h}^{1}$, MBBS, MMed, Kian Hua Barry $\underline{T a n}^{2}$, MBBS, MMed, Sashikumar Ganapathy ${ }^{2}$, MB BCh BAO, MRCPCh
}

INTRODUCTION: Paediatric poisoning accounts for $1 \%$ of daily emergency department presentations. The aim of this study was to review the characteristics and outcomes of paediatric patients who presented with drug overdose over a five-year period.

METHODS: We performed a retrospective review of paediatric poisoning cases at KK Women's and Children's Hospital (KKH), the largest children's public hospital in Singapore, from 1 January 2009 to 31 December 2013.

RESULTS: A total of 1,208 cases of poisoning were seen in KKH's Department of Children's Emergency during the study period. The gender distribution was about equal, with a slight male predominance. The majority of the poisoning cases were accidental. Slightly more than half of the intentional ingestions were of paracetamol and the majority were female patients belonging to the 12-16 year age group. The bulk of poisonings occurred in children aged 1-4 via the oral route, slightly more than half of the oral ingestions consisted of oral medications and a sizeable portion were of household liquids. Mothballs and silica gels accounted for almost a quarter of the solid household products ingested. Slightly less than half of the patients required admission and only a small portion of the admitted patients required intensive or high dependency care.

CONCLUSION: The prognosis of paediatric patients who presented with poisoning in our study was good, with a short median length of stay for those admitted and no fatalities being reported across the span of five years.

Keywords: childhood poisoning, drug overdose, paediatric poisoning

\section{INTRODUCTION}

Paediatric poisoning is an infrequent but important cause of visits to paediatric emergency departments (EDs), accounting for $1 \%$ of daily ED presentations. Demographic studies of toxic exposures in the Singapore population that included this age group have been published previously. ${ }^{(1,2)}$ Multiple similar studies have been conducted in overseas hospitals, across various continents. ${ }^{(3-10)}$ However, in the last decade, there have been no demographic studies on paediatric patients presenting with drug overdose in Singapore. The aim of this study was to review the characteristics and outcomes of paediatric patients presenting with drug overdose over a five-year period from 2009 to 2013. This information will be used to aid future efforts in public poison prevention and poison education among medical personnel.

\section{METHODS}

We performed a retrospective review of paediatric poisoning cases at KK Women's and Children's Hospital (KKH), the largest children's public hospital in Singapore, over a five-year period from 1 January 2009 to 31 December 2013. Ethics committee approval was obtained from the SingHealth Institutional Review Board prior to the commencement of the study. The records of all patients seen at the Department of Children's Emergency, $\mathrm{KKH}$, during the study period were captured electronically in the Online Paediatric Emergency Care system, with their diagnoses coded according to the International Classification of Diseases
(ICD) classification system. These cases did not include cases of poisoning by food, bites or stings, which had been incorrectly coded under the ICD codes for poisoning.

Patients who were suitable for the study were identified through a search of the electronic records using the ICD codes for 'poisoning by alternative western medicine', 'poisoning by non-medicinal substances', 'poisoning by unspecified drug or non-medicinal substance' and 'poisoning by Chinese/Indian/ Japanese/Malay medicine'. Patient data was then further analysed and classified under the following categories: age, gender, time from poisoning to presentation, location, time of day of ingestion, type of drug ingested, reason for drug ingestion, ED management and disposition.

\section{RESULTS}

From 1 January 2009 to 31 December 2013, a total of 1,208 cases of poisoning were seen in the Children's Emergency at KKH. $50.7 \%$ of the patients were male and $49.3 \%$ were female. We included 13 patients above the age of 16 years who presented to the department although they were above the cut-off age for paediatric admissions to our hospital. Of these, two were adult patients aged 30 years and 41 years, while the rest were aged $16-18$ years. $95.4 \%$ of the cases occurred in the home setting, with the rest occurring outside the home. $51.3 \%$ of the cases occurred during the period of 7 am to $7 \mathrm{pm}$, with the rest occurring from $7 \mathrm{pm}$ to $7 \mathrm{am}$. Overall, slightly more poisonings 
Table I. Characteristics of the patients who presented to the Children's ED and their poisoning incidents $(n=1,208)$.

\begin{tabular}{|c|c|}
\hline Characteristic & No. (\%) \\
\hline \multicolumn{2}{|l|}{ Time from poisoning to presentation $(\mathrm{hr})^{*}$} \\
\hline$<1$ & $107(8.9)$ \\
\hline 1 to $<4$ & $665(55.0)$ \\
\hline 4 to $<24$ & $387(32.0)$ \\
\hline$\geq 24$ & $24(2.0)$ \\
\hline \multicolumn{2}{|l|}{ Type of poisoning } \\
\hline Intentional & $128(10.6)$ \\
\hline Accidental & $1,080(89.4)$ \\
\hline \multicolumn{2}{|l|}{ Route of poisoning } \\
\hline Oral & $1,184(98.0)$ \\
\hline Ocular mucosa & $12(1.0)$ \\
\hline Nasal mucosa & $9(0.7)$ \\
\hline Injections (EpiPen, insulin) & $3(0.2)$ \\
\hline \multicolumn{2}{|l|}{ Product involved in poisoning } \\
\hline Oral medications & $609(50.4)$ \\
\hline Antipyretics/analgesics & $189(31.0)$ \\
\hline Antihistamines/cough syrups & $171(28.1)$ \\
\hline Antibiotics & $21(3.4)$ \\
\hline Multivitamins & $12(2.0)$ \\
\hline Others & $216(35.5)$ \\
\hline $\begin{array}{l}\text { Topical creams, ointments, nose/eye drops, } \\
\text { medicated washes }\end{array}$ & $79(6.5)$ \\
\hline Household liquids/products & $510(42.2)$ \\
\hline $\begin{array}{l}\text { Bleach/liquid detergent/floor cleaning } \\
\text { liquid/dishwashing liquids }\end{array}$ & $87(17.1)$ \\
\hline Insecticides/insect bait/insect repellents & $61(12.0)$ \\
\hline Silica gel & $59(11.6)$ \\
\hline Mothballs & $50(9.8)$ \\
\hline $\begin{array}{l}\text { Body soaps/hand sanitisers/shower gels/ } \\
\text { shampoo }\end{array}$ & $41(8.0)$ \\
\hline Perfumes/skin toners/cosmetic creams & $25(4.9)$ \\
\hline Nail polish/nail polish remover & $22(4.3)$ \\
\hline Paint/thinners & $14(2.7)$ \\
\hline Air fresheners & $11(2.2)$ \\
\hline Ethanol & $2(0.4)$ \\
\hline Other household liquids/products & $138(27.1)$ \\
\hline Others & $10(0.8)$ \\
\hline
\end{tabular}

*Data was unavailable for 25 patients. ED: emergency department

occurred in the day (51\%) as compared to the night (49\%). Most patients presented within 24 hours of the poisoning (95.9\%) and $8.9 \%$ presented within one hour of the poisoning. Table I and Fig. 1 show the characteristics of the patients and details of their poisoning incidents.

Decontamination was required in $28.5 \%$ of the cases and antidotes were given in $7.7 \%$ of the cases (Table II). The most common antidote used was $\mathrm{N}$-acetylcysteine for cases of paracetamol poisoning. Among the 1,208 patients, 5.5\% of the cases were seen in the resuscitation room and $94.5 \%$ in the ambulatory area. $600(49.7 \%)$ of the cases were admitted and $608(50.3 \%)$ of them were discharged. Of the patients who were discharged, $44(7.2 \%)$ were discharged at their own risk.

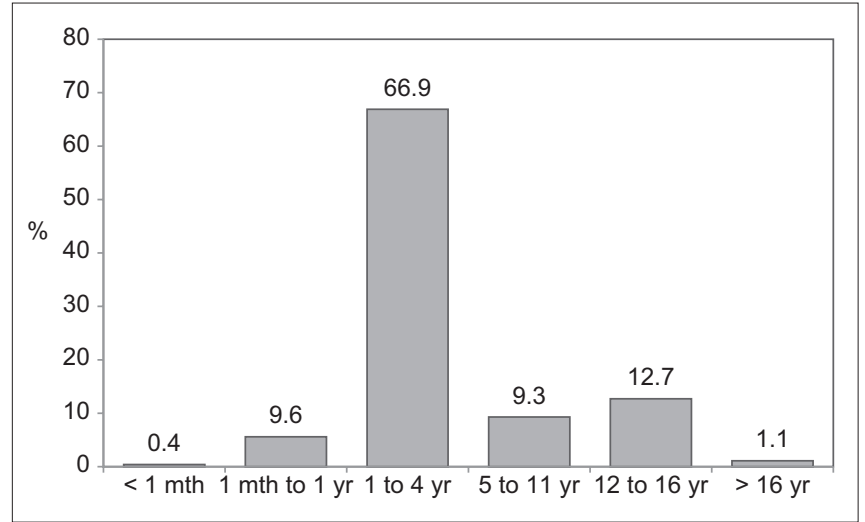

Fig. 1 Bar graph shows the demographic breakdown of poisonings according to age group $(n=1,208)$

Table II. Care and disposition of patients $(n=1,208)$.

\begin{tabular}{|ll|}
\hline Parameter & No. (\%) \\
\hline Decontamination/antidote & \\
\hline Gastric lavage & $42(3.5)$ \\
\hline Activated charcoal & $302(25.0)$ \\
\hline Antidote & $93(7.7)$ \\
\hline Treatment location & \\
\hline Resuscitation room & $67(5.5)$ \\
\hline Ambulatory patients & $1,141(94.5)$ \\
\hline Disposition & $600(49.7)$ \\
\hline Admission & $26(4.3)$ \\
\hline High dependency/intensive care unit & $608(50.3)$ \\
\hline Discharged & $44(7.2)$ \\
\hline At own risk & \\
\hline
\end{tabular}

Of the 600 patients who were admitted, 26 (4.3\%) required high dependency (HD) or intensive care unit (ICU) care. The indications for HD and ICU admission were mainly for closer monitoring and observation.

The details of the patients who required HD or ICU admission are listed in Table III. An analysis of these patients showed that the most common electrolyte abnormality on presentation was mild hypokalaemia. The median length of hospital stay was one day. There were no fatalities.

\section{DISCUSSION}

During the five-year study period, 1,208 cases of paediatric poisoning were seen, accounting for $0.2 \%$ of the total number of attendances at the paediatric emergency department. This number is comparable with similar studies conducted in Turkey and Oslo, which showed that poisoned patients represented $0.1 \%-0.34 \%$ of overall paediatric ED and outpatient visits. ${ }^{(4,6)}$ Meanwhile, poisonings accounted for $0.32 \%-3 \%$ of admitted paediatric patients in studies carried out in Hong Kong, Cyprus, Burkina Faso and Nigeria. . $^{(3,5,7,8)}$

In our study, the gender distribution was about equal, with a slight male predominance. This was in line with the general gender distribution in the paediatric age group. $76.9 \%$ of the paediatric poisoning population comprised of children aged below four years. The bulk of these occurred in children aged 
Table III. Cases that required HDU or ICU admission $(n=26)$.

\begin{tabular}{|c|c|c|c|c|}
\hline $\begin{array}{l}\text { Age }(y r) \\
\text { intent }(I / U)\end{array}$ & Type of poisoning & $\begin{array}{l}\text { Indication for HDU/ } \\
\text { ICU admission }\end{array}$ & $\begin{array}{l}\text { Overall } \\
\text { LOS (day) }\end{array}$ & $\begin{array}{l}\text { Electrolyte } \\
\text { abnormalities }\end{array}$ \\
\hline 15,1 & $\begin{array}{l}\text { Panadol Extra (paracetamol } \\
\text { and caffeine) }\end{array}$ & $\begin{array}{l}\text { Toxic dose } \\
\text { For monitoring }\end{array}$ & 5 & $\begin{array}{l}\text { Hypokalaemia } \\
\text { (K } 3.0 \mathrm{mEq} / \mathrm{L})\end{array}$ \\
\hline 14,1 & Nifedipine sustained release & $\begin{array}{l}\text { High-risk ingestion } \\
\text { For monitoring }\end{array}$ & 3 & Nil \\
\hline $2, U$ & Carbamazepine & $\begin{array}{l}\text { Drowsy } \\
\text { For monitoring }\end{array}$ & 4 & $\begin{array}{l}\text { Hypokalaemia } \\
\text { (K } 3.2 \mathrm{mEq} / \mathrm{L})\end{array}$ \\
\hline $3, \cup$ & $\begin{array}{l}\text { Eucalyptus medicated } \\
\text { oil (salicylate) }\end{array}$ & $\begin{array}{l}\text { Ataxic } \\
\text { For monitoring }\end{array}$ & 2 & $\begin{array}{l}\text { Hypokalaemia } \\
\text { (K } 3.2 \mathrm{mEq} / \mathrm{L})\end{array}$ \\
\hline $15.4,1$ & Methylphenidate & $\begin{array}{l}\text { Toxic dose with tachycardia } \\
\text { For monitoring }\end{array}$ & 1 & Nil \\
\hline 12,1 & Glue & $\begin{array}{l}\text { Concomitant head injury and } \\
\text { facial fractures } \\
\text { For monitoring }\end{array}$ & 21 & $\begin{array}{l}\text { Hypokalaemia } \\
(\mathrm{K} 3.2 \mathrm{mEq} / \mathrm{L})\end{array}$ \\
\hline $2, U$ & Benzodiazepines & $\begin{array}{l}\text { Drowsy } \\
\text { For monitoring }\end{array}$ & 3 & Nil \\
\hline 14,1 & $\begin{array}{l}\text { Propranolol, diclofenac, } \\
\text { mefenamic acid, } \\
\text { domperidone }\end{array}$ & $\begin{array}{l}\text { High-risk ingestion } \\
\text { For monitoring }\end{array}$ & 3 & $\mathrm{Nil}$ \\
\hline $1, U$ & Amitriptyline & $\begin{array}{l}\text { High-risk overdose } \\
\text { For monitoring }\end{array}$ & 1 & Nil \\
\hline $2, U$ & Lorazepam & Apnoea, intubated & 1 & $\mathrm{Nil}$ \\
\hline 15,1 & $\begin{array}{l}\text { Loratadine, ventolin, anarex, } \\
\text { maxolon, cephalexin, } \\
\text { cimetidine, buscopan }\end{array}$ & $\begin{array}{l}\text { Drowsy, HAGMA, hypokalaemic } \\
\text { For monitoring }\end{array}$ & 3 & $\begin{array}{l}\text { Hypokalaemia } \\
\text { (K } 2.9 \mathrm{mEq} / \mathrm{L})\end{array}$ \\
\hline $3, U$ & Salbutamol syrup & $\begin{array}{l}\text { Tachycardic and hypokalaemic } \\
\text { For monitoring }\end{array}$ & 1 & $\begin{array}{l}\text { Hypokalaemia } \\
\text { (K } 2.7 \mathrm{mEq} / \mathrm{L})\end{array}$ \\
\hline 10,1 & $\begin{array}{l}\text { Toilet cleaner } \\
\text { (tea tree oil and solvents) }\end{array}$ & $\begin{array}{l}\text { High-risk ingestion } \\
\text { For monitoring }\end{array}$ & 3 & Nil \\
\hline 14,1 & Alcohol & $\begin{array}{l}\text { Drowsy } \\
\text { For monitoring }\end{array}$ & 1 & $\begin{array}{l}\text { Hypokalaemia } \\
\text { (K } 3.0 \mathrm{mEq} / \mathrm{L})\end{array}$ \\
\hline $1, U$ & $\begin{array}{l}\text { TCM containing } \\
\text { glibenclamide }\end{array}$ & $\begin{array}{l}\text { Drowsy and hypoglycaemic } \\
\text { For monitoring }\end{array}$ & 2 & $\begin{array}{l}\text { Hypoglycaemia } \\
\text { (Glu } 1.2 \mathrm{mmol} / \mathrm{L})\end{array}$ \\
\hline 2.6, U & $\begin{array}{l}\text { Mothball containing } \\
\text { camphor }\end{array}$ & $\begin{array}{l}\text { Seizures } \\
\text { For monitoring }\end{array}$ & 1 & $\mathrm{Nil}$ \\
\hline $2.1, U$ & Lomotil & $\begin{array}{l}\text { High-risk ingestion } \\
\text { For monitoring }\end{array}$ & 2 & Nil \\
\hline 4.6, U & Turpentine & $\begin{array}{l}\text { High-risk ingestion } \\
\text { For monitoring }\end{array}$ & 3 & Nil \\
\hline $1, U$ & $\begin{array}{l}\text { Marker ink } \\
\text { (turpentine/kerosene) }\end{array}$ & $\begin{array}{l}\text { High-risk ingestion } \\
\text { For monitoring }\end{array}$ & 1 & Nil \\
\hline $14, \mathrm{U}$ & $\begin{array}{l}\text { Phenexpect syrup } \\
\text { (diphenhydramine } \\
\text { and ammonium chloride) }\end{array}$ & $\begin{array}{l}\text { High-risk ingestion } \\
\text { For monitoring }\end{array}$ & 2 & Nil \\
\hline $1, U$ & Dextromethorphan syrup & $\begin{array}{l}\text { Drowsy } \\
\text { For monitoring }\end{array}$ & 1 & Nil \\
\hline $5, U$ & Methadone & $\begin{array}{l}\text { Drowsy } \\
\text { For monitoring }\end{array}$ & 3 & Respiratory acidosis \\
\hline $1, U$ & Cinnarizine & $\begin{array}{l}\text { High-risk ingestion } \\
\text { For monitoring }\end{array}$ & 1 & $\begin{array}{l}\text { Hypokalaemia } \\
\text { (K } 3.1 \mathrm{mEq} / \mathrm{L})\end{array}$ \\
\hline 15,1 & Vodka and diazepam & $\begin{array}{l}\text { Drowsy } \\
\text { For monitoring }\end{array}$ & 5 & $\begin{array}{l}\text { Hypophosphataemia } \\
\text { (phosphate } 0.5 \mathrm{mmol} / \mathrm{L} \text { ) }\end{array}$ \\
\hline 15,1 & Paracetamol & $\begin{array}{l}\text { Toxic dose } \\
\text { For monitoring }\end{array}$ & 5 & Nil \\
\hline $0.7, \mathrm{U}$ & Ventolin and theophylline & $\begin{array}{l}\text { Tachycardic, high-risk ingestion } \\
\text { For monitoring }\end{array}$ & 4 & $\begin{array}{l}\text { Hypercalcaemia } \\
\text { (Corrected Ca } 2.89 \mathrm{mmol} / \mathrm{L} \text { ) }\end{array}$ \\
\hline
\end{tabular}

Ca: calcium; Glu: glucose; HAGMA: high anion gap metabolic acidosis; HDU: high dependency unit; I: intentional; ICU: intensive care unit; K: potassium; LOS: length of stay; TCM: traditional Chinese medicine; U: unintentional. 
1-4 years via the oral route, which was an unsurprising finding given that children at this age are ambulant, curious about their surroundings and have not learnt to discriminate between poisons and edible food.

A majority of the cases were accidental, a finding similar to that seen in other studies. In contrast, a majority of the cases among the adult ED population tend to be intentional. ${ }^{(1)}$ Slightly more than half of the intentional ingestions consisted of paracetamol, and the majority were female patients belonging to the 12-16 years age group, a finding similarly seen in the Hong Kong study. ${ }^{(3)}$ The bulk of the cases (95.4\%) occurred in the home setting. This is unsurprising, given that a large proportion of potential poisons are found in the home environment.

Following the onset of the poisoning, most patients presented within 24 hours (95.9\%). A small proportion (8.9\%) presented within one hour of the poisoning, during the important time window in which gastric decontamination can be carried out in the forms of gastric lavage or activated charcoal.

A large proportion of the ingestions were via the oral route $(98.0 \%)$, with predominantly oral medications and household liquids. These ingestants are usually brightly coloured in attractive packaging and easily accessible around the house, thus accounting for their high incidence of ingestion by children. Of note, antipyretics, analgesics, antihistamines and cough syrups were commonly ingested, as they are the most common medications prescribed to ill children. Mothballs and silica gels accounted for almost a quarter of the solid household products ingested, which was likely to be due to their ubiquitous nature and easy accessibility to children in most households. Unsurprisingly, acetylcysteine was the most common antidote given in the ED, given the significant number of cases of intentional poisoning via paracetamol ingestion.

Slightly less than half of the patients required admission $(49.7 \%)$, a significantly lower percentage than that reported in the Turkish study (69.1\%).. ${ }^{(4)}$ Also, only a small portion of the admitted patients in our study required ICU or HD care $(4.3 \%)$, unlike in the Turkish study (46.6\%). These differences can largely be attributed to the difference in the lethality of the poisons ingested. In the Turkish study, for example, there was a significant number of poisonings by carbon monoxide and amitriptyline, which were hardly seen in our ED.

All of the patients with intentional overdoses were admitted for further inpatient medical social worker assessment. In unintentional cases of poisoning, routine counselling with regard to future prevention of similar events was given by doctors to the patients and their caregivers prior to discharge. In cases where poisoning occurred with a background of possible parental neglect or stressful home environment, medical social worker referrals were made.

The prognosis of paediatric patients who presented with poisoning in our study was good, with a short median length of stay for those who were admitted. Remarkably, no fatalities were reported across the span of five years. To our knowledge, this is the largest study that focused on paediatric poisoning in Singapore, and gives a good snapshot of the current burden of paediatric poisoning here.
This study was not without limitations. It was a retrospective review of poisoning data and only includes poisonings presenting to the ED of one public hospital. Minor poisoning cases that presented to the primary healthcare setting or were self-treated, as well as fatality cases that did not make it to the hospital, were not captured in this study. As case identification involved ICD code data mining from hospital computerised databases, data capture was likely to be incomplete, with an expected underestimation of the actual caseload.

In conclusion, our results underscore the need for poison prevention programmes to target the caregivers of patients in the toddler age group, as well as adolescent girls who are at increased risk of poisoning due to deliberate self-harm. This is particularly pertinent in situations where both parents are working, or where the social environment is tenuous with family conflict. We think that our data would help to justify the creation of a dedicated drug and poison information centre and/ or hotline in our country, which currently does not exist. The role of such a centre would be multifold. Firstly, it could aid hospital staff in providing evidence-based and cost-effective management of poisoning cases. Secondly, it would provide useful information to general practitioners and paediatricians in the ambulatory setting, thereby reducing the burden of poisoning cases (most of which do not require admission) for the EDs of hospitals. Such a centre could also lead the way in educating the medical community at large on management of poisonings from frequently implicated products seen in the study (i.e. mothballs and antipyretics). Finally, such a centre would also be useful in the coordination and implementation of poison prevention programmes to increase awareness of poisonings and the need for post-poisoning early assessment among the general public. Examples of such programmes include teaching parents and caregivers ways to safely place medications and household products to limit inappropriate access of vulnerable children at home. Hopefully, such initiatives would help to decrease the incidence of preventable cases of poisoning.

\section{REFERENCES}

1. Ponampalam R, Tan HH, Ng KC, Lee WY, Tan SC. Demographics of toxic exposures presenting to three public hospital emergency departments in Singapore 2001-2003. Int J Emerg Med 2009; 2:25-31.

2. Ho L, Heng JT, Lou J. Accidental ingestions in childhood. Singapore Med J 1998; 39:5-8.

3. Hon $\mathrm{KL}, \mathrm{Ho} J \mathrm{~K}$, Leung TF, et al. Review of children hospitalised for ingestion and poisoning at a tertiary centre. Ann Acad Med Singapore 2005; 34:356-61.

4. Andiran N, Sarikayalar F. Pattern of acute poisonings in childhood in Ankara: what has changed in twenty years? Turk J Pediatr 2004; 46:147-52.

5. Koliou M, loannou C, Andreou K, Petridou A, Soteriades ES. The epidemiology of childhood poisonings in Cyprus. Eur J Pediatr 2010; 169:833-8.

6. Rajka T, Heyerdahl F, Hovda KE, Stiksrud B, Jacobsen D. Acute child poisonings in Oslo: a 2-year prospective study. Acta Paediatr 2007; 96:1355-9.

7. Kouéta F, Dao L, Yé D, Fayama Z, Sawadogo A. [Acute accidental poisoning in children: aspects of their epidemiology, aetiology, and outcome at the Charles de Gaulle Paediatric Hospital in Ouagadougou (Burkina Faso)]. Sante 2009; 19:55-9. French.

8. Oguche S, Bukbuk DN, Watila IM. Pattern of hospital admissions of children with poisoning in the Sudano-Sahelian North eastern Nigeria. Niger J Clin Pract 2007; 10:111-5.

9. Pillai GK, Boland K, Jagdeo S, Persad K. Acute poisoning in children. Cases hospitalized during a three-year period in Trinidad. West Indian Med J 2004; 53:50-4.

10. Goto K, Endoh Y, Kuroki Y, Yoshioka T. Poisoning in children in Japan. Indian J Pediatr 1997; 64:461-8. 